\title{
Atlantis
}

Critical Studies in Gender, Culture \& Social Justice

Études critiques sur le genre, la culture, et la justice

\section{Locating Feminist Progress in Professional Military Education}

\section{Vanessa Brown}

Volume 41, Number 2, 2020

Gender and the Canadian Armed Forces

URI: https://id.erudit.org/iderudit/1076198ar

DOI: https://doi.org/10.7202/1076198ar

See table of contents

Publisher(s)

Mount Saint Vincent University

ISSN

1715-0698 (digital)

Explore this journal

Cite this article

Brown, V. (2020). Locating Feminist Progress in Professional Military Education. Atlantis, 41(2), 26-41. https://doi.org/10.7202/1076198ar

\section{Article abstract}

A continuing debate in feminist scholarship on gender, security, and the military has been whether militaries can facilitate feminist progress and be forces for good. Feminists committed to working outside of militaries note that gender perspectives have often been used to advance the military's goals of winning wars rather than commitments to feminist social transformation of military institutions and societies. However, influences from international normative frameworks on Women, Peace and Security; Canada's feminist foreign policy; and an emphasis on diversity and inclusion within Canada's Defence Policy have presented the Canadian Armed Forces with a solid platform from which it has begun to make change. The central tenets of this broad feminist platform have begun to permeate Canadian Professional Military Education (PME) through the collective efforts of educators, staff, and military students at Canada's defence colleges. Drawing on a review of policy and programmes as well as a qualitative analysis of interviews with educators, staff, and military students, the article demonstrates that feminist transformational change by military members is possible by exploring its nascent reality. The article highlights the challenges and benefits of incorporating feminist perspectives in Canadian PME and demonstrates how and under what conditions military graduates with this education have begun to apply gender and cultural learning to make local feminist interventions both within and outside their institution. Ultimately, this research shows that collective efforts toward localized and incremental changes by military members are paving the way for meaningful feminist progress within the military.
All Rights Reserved (c) Vanessa Brown, 2020

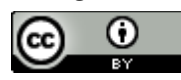

This document is protected by copyright law. Use of the services of Érudit (including reproduction) is subject to its terms and conditions, which can be viewed online.

https://apropos.erudit.org/en/users/policy-on-use/ 


\section{Locating Feminist Progress in Professional Military Education}

Vanessa Brown is an assistant professor at the Dallaire Centre of Excellence for Peace and Security within the Canadian Defence Academy. She facilitates graduate level learning in senior officer education programmes offered by the Canadian Forces College. Vanessa teaches in the broad areas of military sociology, gender and security, military leadership, operations, and policy. Her graduate research and written work focus on gender, intersectionality, and (in)security through the domain of Professional Military Education and the institutional social dynamics of the Canadian Armed Forces.

Abstract: A continuing debate in feminist scholarship on gender, security, and the military has been whether militaries can facilitate feminist progress and be forces for good. Feminists committed to working outside of militaries note that gender perspectives have often been used to advance the military's goals of winning wars rather than commitments to feminist social transformation of military institutions and societies. However, influences from international normative frameworks on Women, Peace and Security; Canada's feminist foreign policy; and an emphasis on diversity and inclusion within Canada's Defence Policy have presented the Canadian Armed Forces with a solid platform from which it has begun to make change. The central tenets of this broad feminist platform have begun to permeate Canadian Professional Military Education (PME) through the collective efforts of educators, staff, and military students at Canada's defence colleges. Drawing on a review of policy and programmes as well as a qualitative analysis of interviews with educators, staff, and military students, the article demonstrates that feminist transformational change by military members is possible by exploring its nascent reality. The article highlights the challenges and benefits of incorporating feminist perspectives in $\mathrm{Ca}$ nadian PME and demonstrates how and under what conditions military graduates with this education have begun to apply gender and cultural learning to make local feminist interventions both within and outside their institution. Ultimately, this research shows that collective efforts toward localized and incremental changes by military members are paving the way for meaningful feminist progress within the military.

Keywords: Canadian Armed Forces, feminist, gender, intersectionality, leadership, military, Professional Military Education

The views expressed in this article are solely those of the author. They are not intended to reflect the views and values of the Department of National Defence or the Canadian Armed Forces. This research was granted ethics approval by Carleton University Ethics Review Board, which follows national standards for the conduct of research involving human subjects outlined by the TriCouncil Policy Statement. The research has also been approved through coordination with DGMPRA Social Science Research Review Board, with the finding that the research falls under the programme evaluation category in accordance with DAOD 5062-0 and 5062-1. 
$\mathrm{A}^{\mathrm{s}}$ $s$ a feminist anti-racist scholar researching the integration of gender and cultural perspectives in the Professional Military Education (PME) of Canadian military personnel, I have struggled intellectually and personally with the possibility for transformational change within militaries as well as the potential for militaries to be "forces for good" (Duncanson and Woodward 2016, 13). After all, militaries are sanctioned by states to apply lethal violence. Their members are called upon to kill or be killed (Ibid.). Historically, military violence has served to uphold the world's most oppressive socially constructed systems: patriarchy, colonialism, imperialism, and capitalism (Razack 2004). These systems of oppression are noted to be reproduced in militaries including the Canadian Armed Forces (CAF) through intense processes of military socialization (Whitworth 2005). On the other hand, militaries have been used to end conflict, protect civilians, and provide humanitarian aid and disaster response domestically and internationally. In the process, militaries have been engaged in improving women's social, political, economic, and legal conditions particularly through the implementation of the Women, Peace and Security agenda, a set of United Nations Security Council Resolutions aimed at achieving gender equality and addressing the disproportionate impact of crises and conflict on women and girls (Kirby and Sheppard 2016). Thus, the military's relationship to feminist progress is complicated. In view of this complicated relationship, might militaries be capable of transforming the very systems of oppression they have traditionally helped to develop and reproduce?

The question of whether the military can be a force for good continues to present a significant dilemma for feminists. There has been recurring debate on whether feminist scholars should work to intervene to transform the inner workings of militaries in hopes of making feminist change from within (Duncanson and Woodward 2016). Some feminists committed to working outside of militaries note that feminist goals of gender equality are often eclipsed by institutional goals of operational effectiveness and winning wars (Cockburn 2011). However, international organizations such as the United Nations (UN) as well as states have increasingly privileged militaries as primary actors in the provision of peace and security (Kirby and Sheppard 2016). Thus, expecting the military to do this work without feminist engagements from within could result in militaries pushing feminist conceptions of peace and security even further from feminist visions. While some feminists choose to forgo relationships with the military altogether and focus attention on collaboration and advocacy with non-governmental organizations and civil society groups (Cockburn 2011), other feminists argue that it is possible to shape the content and process of military engagements in peace and security for good (Duncanson and Woodward 2016).

Indeed, influences from international normative frameworks on peace and security, Canada's Feminist Foreign Policy (adopted in 2017 following Sweden's lead), and a focus on gender and diversity within Canada's Defence Team have created a solid platform from which the CAF has begun to make change. The Canadian military has committed to creating an inclusive culture where each member is treated with dignity and respect (Chief of Defence Staff 2009). It has also committed to applying gender perspectives and analyses in all mission plans and actions (Chief of Defence Staff 2016b). But does this change within the military indicate feminist progress? Drawing from research on transformational change within militaries as well as findings from my $\mathrm{PhD}$ research, I provide a "conceptual approach to understand how, and under what circumstances, militaries can change" and support feminist progress (Duncanson and Woodward 2016, 11). Feminist progress in militaries could include work towards more equitable and inclusive working conditions for women, men, and non-binary personnel with diverse ethnicities, languages, cultures, gender identities, sexualities, and abilities. Feminist progress through military engagements could mean exploring the military's role in the facilitation of gender equality in societies and pursuing ways and means to prevent violence against the most marginalized groups in Canada, and societies abroad. More broadly, feminist progress through military engagement could mean working to understand how policies, plans, and actions of the Canadian military 
could lead to inclusive security and enduring peace for all people.

I argue that feminist progress of this sort is possible with concerted efforts to support military professionals in learning about the root causes of social, political, and economic inequality in the military and societies, and the military's role in facilitating change. I posit that military members can be important agents for change when: they become aware of and work to confront masculinist institutional norms and oppressive intersectional social orders (Razack 2004; Taber 2015); they commit to a process of "regendering" to redefine the soldierly identity as inclusive of femininities, masculinities, women, men, and non-binary people, as well as racialized, sexual, and linguistic diversity (Duncanson and Woodward 2016); they reframe professionalism around principles of recognition, equality, empathy, care, and respect (Ibid.); and they examine and work to address inequalities within the military, domestically and internationally.

In this article, I show that the integration of gender and cultural perspectives within PME can help military members to achieve the institution's goals of fostering an inclusive military culture and facilitating feminist objectives within the Women, Peace and Security agenda in domestic and international engagements (Chief of Defence Staff 2016b). PME programmes like the graduate level learning offered in the Joint Command and Staff Programme (JCSP) have promise precisely because they can include curriculum that helps to highlight the ways in which gender and intersectional inequalities are perpetuated systemically, institutionally, and interpersonally. These programmes can be mechanisms through which Canadian military personnel achieve greater awareness and understanding about social inequalities outside of, but also within, the institution. Yet in their current form, initiatives to integrate these perspectives in training and education have not been enough to create the institutionally desired critical thinking capacities in military members that are required to create culture change within the military and to facilitate gender equality domestically and internationally (Chief of Defence Staff 2016b). As my research illuminates, education on the critical race, feminist, and intersectional theories behind Gender-based Analysis Plus (GBA+; described in greater detail below) is necessary for military professionals to fully understand how to apply this tool. In addition, my research illuminates how the incorporation of gender and cultural perspectives in curriculum helps military members to achieve the military's commitments to the Women, Peace and Security agenda (Chief of Defence Staff 2016b). This institutionally mandated feminist progress (Ibid.) requires the calibre of feminist training and education only made possible through the concerted efforts of military and civilian faculty and staff.

This article demonstrates that transformational change within the military is possible by empirically exploring its nascent reality. In the first section, I build the case for this position by presenting feminist thinking on gender and security and the potential for militaries to facilitate transformational change. This presentation is followed by a review of feminist work in PME to incorporate gender and cultural perspectives in curriculum, to create inclusive learning environments, and to apply feminist pedagogy. The next section describes the qualitative ethnographic methods I employed to collect data as well as my application of Critical Discourse Analysis to interpret the data collected. The remaining sections highlight findings on the impact of integrating feminist theory and frameworks in the PME of senior officers to feminist progress in the $\mathrm{Ca}$ nadian military. Drawing from the narratives of research participants, I explore how military professionals have applied gender and cultural learning to make local feminist interventions. Ultimately, I demonstrate that "what might seem like limited progress, or superficial changes" made by military members could pave the way for meaningful feminist transformations (Duncanson and Woodward 2016, 11).

\section{Feminist Thinking on Gender and Security: Towards Transformational Change}

Patriarchal societies - those in which social organization upholds men's normative and material control over social, economic, and political power-ascribe in 
varying degrees to a two-sex system (Shildrick 1997). In a two-sex system, body parts, chemistry, and bodily practices are constructed in hierarchical and binary ways that classify individuals into two distinct and differentially valued biological sexes - male and female (De Beauvoir 1949). The physical materiality of bodies is grounded in what bodies essentially are and what they essentially do (Butler 2007; Cook 2007). What is understood as socially innate to men and women, however, happens through myriad and historical processes of gender socialization to embody idealized archetypes of masculinity and femininity. These narratives often include normalized and taken-forgranted conceptions of men as natural soldiers and leaders with the relational understanding of women as requiring male leadership and protection (Elshtain 1987). In this way, while sex is a biological category, gender is a social one. In the military, members are consistently engaged in the social process of aligning with institutionally idealized masculine characteristics and norms associated with the soldierly identity.

While the ways in which each body is understood and valued in patriarchal societies is subjective, all patriarchies privilege masculinity. Material power and resource inequalities between women and men happen culturally and ideologically through the "elevation of ways of being and knowing associated with men and masculinity over those associated with women and femininity" (Hooper 1998, 31 cited in Eichler 2014, 83). Masculinist ideologies in societies tend to make invisible the processes through which men and masculinity gain status, authority, and power over women and femininities by presenting male power as inevitable, natural, or desirable_-including in the running of states and militaries (Ibid.). Feminist research demonstrates the various ways in which gender is socially constructed in diverse societies (Hacking 1999) and speaks to the supposition that associations about masculinities, or "what men do," and femininities, or "what women do," have the possibility to be constructed differently (Schippers 2007). In other words, as gender is a social construction, it is subject to transformational change (Duncanson 2015). The dominant gender order does not have to be this way, and as such, through scholarship and practice feminists have pursued recognition, justice, redistribution, and equality.

A key insight from the field of feminist International Relations and feminist sociological theory is that war and conflict are deeply gendered (Cockburn 2010; Segal 2008). Oppressive gender dynamics are relational to power and struggle in and among societies. In many ways, gender is ritualized and normalized, and masculinity's privileged status is continually performed and legitimized through expressions of power, control, and dominance (Butler 2007). As such, patriarchal social organization predisposes societies to the underlying antagonisms of conflict (Cockburn 2010). But gender is not the only social system underlying conflict. Gender relations are interwoven with connecting and mutually constituting systems of power such as racialization, imperialism, and coloniality (McClintock 1995; Razack 2004), sexuality (Duriesmith 2019; Eriksson Baaz \& Stern 2009; Theweleit 1987), economic factors and systems (Cockburn 2010), clashes of cultures, ethnic, and religious communities (Duriesmith 2017; Kaldor 2012), as well as control and struggle between states and nation-states (Cockburn 2010, 139).

Feminists have also demonstrated how gender is used to justify war. Gender has been used in narratives that attempted to legitimize and draw popular support for both World Wars, the Cold War, the First Gulf War, the Yugoslav Wars, the Second Chechen War, and the ongoing conflicts in Afghanistan and Iraq (Sjoberg 2011, 121). Gendered narratives of good and bad guys, protector and protected, civilized and brutish, and good and bad masculinity influence and shape conflict. As Claire Duncanson notes, "the association of masculinity with toughness, aggression, and war, and femininity with weakness, passivity, and peace privileges 'tough' responses to conflict and feminizes nonviolent alternatives, reinforcing the systems of war and militarism" $(2015,235)$.

Militaries often draw on these gendered dualisms to "persuade people (mostly men) to fight" (Sjoberg 2011, 122). Examinations of the Canadian military (Davis 2007; Whitworth 2005) and British Armed 
Forces (Woodward and Winter 2007) demonstrate that militaries tend to draw on idealized notions of manhood in relation to the military identity. Laura Sjoberg explains that tropes, stereotypes, and archetypal identities of bravado, virility, and masculinity are common across militaries. Her work demonstrates that sexist jokes, name calling, and chants are used to shape the sorts of gendered behaviours militaries associate with warriors (Sjoberg 2011, 122). She explains "rather than just being incidental, this sexist language and behavior is endemic" as militaries very intentionally use gendered narratives to turn ordinary people into soldiers (Ibid.).

Yet, the processes through which ordinary citizens are made and molded into soldiers are unique to each military's culture (Masters 2005; Sasson-Levy 2003; Segal 1999). Hence, idealized identities within militaries are relational to militaries' unique histories, norms, and contexts. Those military masculinities that rise to ascendency do so in constant negotiation with other competing militarized masculinities and femininities (Duncanson 2015; Parpart and Partridge 2015).

For example, my research as well as Duncanson's (2015) study of the British Armed Forces indicates that militarized masculinities and femininities do not always promote violence and masculinist values, though they often do. Our mutually reinforcing research demonstrates that the military is also capable of constructing masculinities and femininities that do not support patriarchal social arrangements but facilitate conditions for transformative change both within armed forces and societies. These more transformational gender constructions are in competition with dominant constructions which do uphold patriarchal social orders. As the following section demonstrates, feminist pedagogy in PME has worked to expose patriarchal social orders and highlight the capacity for militaries and societies to work for change.

\section{Applications of Feminist Pedagogy in PME}

Historically, militaries have spent significant resources and attention on the education of their officers, espe- cially in relation to winning wars, understanding shifts in geopolitical contexts (Allen 2010), and the resultant "changing needs of military learners" (Persyn and Polson 2012, 5-6). Since the Cold War's end, increased complexities and changes in military missions and operations have triggered calls for critical thought, empathy, and intellectual flexibility $(2012,453)$. Several nations, the United States in particular, have renewed focus on investigating and influencing local cultures (Brown and Okros 2018). Moreover, research on the delivery and applications of PME have often concentrated on its value in increasing military competencies and effectiveness, specifically in aligning military thinking with military ethos, doctrine, and ideology (Brown and Syme-Taylor 2012; Taber 2009). PME is also typically reactive to events that have led to civil mistrust of the armed forces. For example, revisions to Canadian PME to include education on military ethos and values of dignity and respect occurred in the wake of the 1993 military scandal known as the Somalia Affair, referring to the torture and murder of Shidane Arone by Canadian military personnel (Whitworth 2005). Additional revisions to include education on harmful and inappropriate sexual behaviour were influenced by findings of the Deschamps Report (2015) that confirmed the military's sexualized culture. These changes are illustrations of the use of PME to set the military on the right side of civil-military relations, and to align the thinking of officers to value the dignity and respect for all persons (Brown and SymeTaylor 2012; Taber 2009).

Nancy Taber argues that what is needed in the current context is education that is focused on feminist transformations of the Canadian military's organizational culture by challenging binary gender constructs and destabilizing masculinism (Taber 2018, 105). I suggest that the groundwork for such feminist advances in PME has already been laid by the interventions of, largely, women activists who lobbied for international policy to break down hierarchical gender relations and transform patriarchal systems of power, including militarism (Cohn 2008). Their work seeks to increase global awareness about the differential impact of violence, conflict, and poverty on women and girls. It was their advocacy that resulted in the adoption of the 
Convention on the Elimination of All Forms of Discrimination against Women (1979), the Beijing Declaration and Platform for Action (1995) (UN Women), UN Security Council Resolution (UNSCR) 1325 and related resolutions on Women, Peace and Security (WPS). These international instruments have called on UN member states to work towards gender equality and consider the differential impact of conflict particularly for women and girls (UNSCR 2000). They have been used by feminist military and civilian faculty to push for the inclusion of gender and cultural perspectives within Canada's PME programmes (Brown and Okros 2018) including the Joint Command and Staff Programme (JCSP).

Drawing on these frameworks, current policy and guidance on the application of gender perspectives in the CAF such as the Chief of Defence Staff directive on the integration of UNSCR 1325 (Chief of Defence Staff 2016b) and the Gender Aide-Memoire (2019) have opened up space for educators to facilitate military professionals to consider the root causes of conflict, unequal systems such as gender, race, economic and social class, and their cultural specificity in PME. These instruments have further enabled feminists within Canadian military colleges to push critical thinking about hierarchical gender orders, masculinism, and militarism both inside and outside of the military.

\section{Methods}

My methodological approach intentionally aimed to advance gender equality and anti-racism in the process of conducting research. To do this I drew from literatures on intersectionality, militarized masculinities, and postmodern feminism to inform my sociological and ethnographic research questions, to look for and interpret themes within the data collected, and to make concrete recommendations for continued feminist change. Drawing from a review of primary literature as well as qualitative in-depth interviews and focus groups, my investigation was guided by the following questions: To what extent have gender and cultural perspectives been integrated into JCSP curriculum? If and in what ways have military socialization and cul- ture shaped the learning environment and influenced the reception of gender and cultural education? Finally, if and in what ways has this learning facilitated feminist transformations and institutional culture change?

I employed multiple methods to conduct this research. The initial stages of research included information collection on policy guiding the integration of gender and cultural perspectives in PME and a review of curriculum, learning outcomes, evaluation/assessment guides, and syllabi to uncover the extent to which gender and cultural perspectives have been integrated into JCSP. The following stages comprised Critical Discourse Analysis (Dijk 1993) of the semi-structured interviews I conducted in the form of focus groups and individual interviews (Deschaux-Beaume 2012). Ethnographic data was collected in six semi-structured focus groups and 16 in-depth interviews that gleaned observations and experiences from staff and students at Canadian Forces College (CFC). Participants were recruited through internal College email which solicited volunteers interested in sharing their experiences with the integration of gender and cultural perspectives in JCSP curriculum. This sampling method may have resulted in capturing bias for the integration of gender and cultural perspectives in curriculum, particularly among individual interview participants. Of note, however, focus groups served as a counterbalance as they contained a broad range of opinions, as those who were curious about, or vocally opposed to the integration of gender and cultural perspectives did attend. In addition, focus groups and interviews were arranged across the College's various subgroups of curriculum developers, deliverers, and students to gain a fulsome understanding of the social setting and culture.

The first set of focus groups were intentionally sex segregated to capture the diversity of gendered experiences among same sex groups. These focus groups drew from the perspectives of female $(n=10)$ and male $(\mathrm{n}=10)$ student volunteers enrolled in JCSP. Focus groups were also conducted with volunteers from Military Faculty $(\mathrm{n}=8)$, military Curriculum and Training Developers ( $\mathrm{n}=7)$, Information Resource Centre staff $(n=6)$, and civilian Academic Faculty $(n=4)$. In-depth 
individual interviews were conducted with nine additional students (female $\mathrm{n}=3$ and male $\mathrm{n}=6$ ). Individual interviews were also conducted with Military Faculty $(\mathrm{n}=3)$, civilian Academic Faculty $(\mathrm{n}=2)$ and Information Resource Centre staff ( $\mathrm{n}=2)$. Follow-up interviews were then conducted with eight graduates of JCSP ( $n=$ 4 females, $n=4$ males) after they had been in staff and leadership roles for a minimum of three months. These follow-up interviews aimed to assess if and how graduates applied learning about gender and cultural perspectives such as gender-based and intersectional analysis and content on diversity, equity, and inclusion to their daily work in the military, and if this learning facilitated efforts toward culture change desired by the institution (Chief of Defence Staff 2016b).

\section{Policy Review Findings}

Findings from my initial review of policy show the commitments Canada has made to international policy that advances gender equality and the WPS agenda. As explained in detail below, these high-level policy commitments have been further articulated in national defence and internal military policy in ways that have direct implications for PME. These commitments have led to institutional policy within the Department of National Defence (DND) and CAF to mainstream gender perspectives across all aspects of their work and to incorporate gender and intersectional perspectives into military training and education. As signatory to the Beijing Platform, Canada committed to mainstreaming gender perspectives in all its policies and programs (UN 1995, s. 202). In 1995, the Canadian government formally adopted a Gender-based Analysis (GBA) approach to be used across federal departments and agencies (Office of the Auditor General 2009). In 2011, GBA+ was introduced (Status of Women Canada 2018a). The plus "goes beyond biological (sex) and socio-cultural (gender) differences" to examine "many other identity factors, like race, ethnicity, religion, age, and mental or physical disability" (Status of Women Canada 2018b). Canada's defence policy notes the intent to leverage the CAF to advance the meaningful participation and empowerment of women and to apply GBA+ institutionally, domestically, and internationally (National Defence 2017).
The defence policy also "commits to gender equality and providing a work environment where women are welcomed, supported and respected" (Ibid., 21). It stresses that "training and education are at the core of the Defence Team's commitment to GBA+ as a means to advance gender equality in Canada" (Ibid., 24). In 2016, the Chief of the Defence Staff issued a directive for the military "to integrate...GBA+ into its operational planning, conduct of missions, and across its institutions" (Chief of Defence Staff 2016b, s. 10). The directive asserts that in an effort to mainstream GBA+ across the Canadian military "the initial focus will be the integration of these considerations into the design and delivery of operational effect" by "incorporating GBA+ into CAF training and education" (Ibid., s.13).

The directive also intends to "spur cultural change, by requiring all members of DND-CAF to familiarize themselves with GBA+ and to take responsibility for its implementation" (Johnstone and Momani n.d.). However, a significant challenge presents itself in developing the calibre of education and training necessary for military members to acquire competencies in applying gender and intersectional perspectives across a range of functions and responsibilities. Currently, all CAF personnel are required to complete a GBA+ training module. This course is under two hours and is directed broadly to federal department personnel (Status of Women 2018b). The military also has a GBA+ infrastructure that includes: a Joint-Responsibility Centre on GBA+ with Directors appointed to oversee GBA+ initiatives; Gender Advisors (who give advice to Commanders responsible for the integration of GBA+ in plans, actions, and evaluations); and Gender Focal Points (tasked with assisting the integration of GBA+ within their branches) (Johnstone and Momani n.d.). In theory, Gender Advisors and Gender Focal Points receive requisite training on the theoretical frameworks of GBA+ and its applications to military plans and actions. In practice, however, there is a significant gap to be filled in both the training available and the adequacy of present education (Brown 2018).

CAF Gender Advisors can attend courses approved by NATO (Swedish Armed Forces 2020) as well as courses on WPS and gender perspectives offered by the 
Australian Defence Force (Australian Government 2020) and British Ministry of Defence (2020). Aside from a mobile NATO Gender Advisor course offered at CFC in 2018, Gender Advisor training of this nature is not yet offered by the Canadian military (Brown 2018). However, a two-day course on GBA+ that qualifies Defence Team members as Gender Focal Points is available (Global Affairs Canada 2018).

There are also additional institutional policies that influence the integration of gender and intersectional perspectives within PME. For example, Operation HONOUR aims to eliminate inappropriate sexual behaviour and calls for culture change led by Canadian military leadership and increased education on harassment prevention (Chief of Defence Staff 2015, s. 1314). The CAF Diversity Strategy also calls for increased diversity, inclusion, and culture change (Chief of Defence Staff 2016a). These institutional policies serve to improve the social status and power of women within the organization, and ultimately place women's right to freedom from violence and discrimination into a policy framework that has been translated into curriculum in PME.

However, ongoing challenges with the inclusion of women and members of diverse sexualities and ethnicities within the Canadian military can make transformational possibilities for CAF difficult to imagine. Historically, any progressive change to diversify Canadian military demographics was a consequence of external pressure and not directly because of an institutional desire to evolve (Madsen 1999). Systemic gender and intersectional inequalities present in the Canadian military include challenges with the integration and treatment of women (Davis 2007) and LGBTQ2I personnel (Okros and Scott 2015); institutionalized racism and challenges with the integration of Indigenous peoples and people of colour within the institution (Joost 2015; Razack 2004; Whitworth 2005); as well as a sexualized culture hostile to women and LGBTQ2I members (Deschamps 2015).

While CAF reproduces gender and intersecting inequalities, there are areas in which the institution has also demonstrated its work towards change. While doctrine such as Duty with Honour (Chief of Defence Staff 2009) as well as programmes and direction such as the Standards of Harassment and Racism Prevention, Operation HONOUR (Chief of Defence Staff 2015), and the CAF Diversity Strategy (Chief of Defence Staff 2016a) have been reactive to the publicity of systemic issues within the military, these frameworks have created a foundation for critical thought. While these programmes have not been enough to foster meaningful transformations within the institution, the expansion of feminist and intersectional learning in PME provides hope that meaningful transformation can be achieved.

\section{Ethnographic Findings}

JCSP has gradually added content on gender and cultural perspectives over the years and offers modules on GBA+ in operations and institutional policy, gender and military socialization, and diversity and identity (Brown 2018). Notwithstanding these advances, there are a range of organizational challenges that contribute to apathy and resistance to critical gender and intersectional thought. Using Critical Discourse Analysis, I was able to identify these challenges in the discourses produced, circulated, and negotiated among participants. In doing so, I traced common narratives of participants to determine the extent to which social practices that produce gender inequality and equality were proliferated through language and what hegemonic processes were represented in alliances, discords, and silences within focus groups.

The challenges can be grouped into three broad areas. The first area is the ad hoc and superficial way in which gender and cultural perspectives were often presented within the curriculum. Second, participants observed a masculinist culture that privileged a narrow intersectional identity of male, white, and masculine warriors. The warrior identity and masculinist culture were observed to be roadblocks to thinking critically about unequal gender relations. Third, participants noted unsatisfactory explanations of gender and racial inequalities, and of tools such as GBA+. This inadequate explanation, participants observed, created con- 
fusion about intersectional inequalities and discrimination and was perceived to lead to apathy about feminist change within the military and in societies. Despite these challenges, participants also noted that the curriculum on gender and cultural perspectives that did resonate well enabled them to challenge their latent biases, raise awareness about intersecting inequities, and work towards change.

\section{Ad hoc and Superficial Presentations of Gender and Cul- tural Perspectives}

Participants commonly observed a fair degree of resistance to the presentation of gender and cultural perspectives by College leadership and educators due to existing intersectional social hierarchies and exclusionary cultural practices. Many expressed that hierarchies and internal resistance equated to ad hoc presentations and sometimes poor delivery of these ideas. Despite recognition of narrow idealizations of militarized masculinity in the culture at CFC, many participants reflected that the education on gender and cultural perspectives that was delivered effectively enabled a shift in their perspectives. Some noted that the lessons they received helped them to identify and disrupt the privileging of maleness, masculinity, and whiteness in the learning environment. These efforts indicate that gender and intersectional learning can set conditions for military students and College staff to think critically and engage in discussion about gender and cultural inequality in the classroom, the institution, Canada, and society more broadly.

As the following reflection of a female graduate demonstrates, the superficial way in which gender and cultural perspectives are sometimes taught may present a barrier to their reception:

This is the challenge. We are trying to provoke a culture change with giving two PowerPoint presentations.... It has to be incorporated in everything that we do, otherwise we will never get there. We need to change the way leaders are thinking and the way that the troops are respectfully interacting with their peers.

Participants of my study observed that there is oppor- tunity for the College to erode barriers to gender and cultural education by mainstreaming these areas across programming. In doing so, participants reflected that CFC could become an international leader among PME institutes by offering more robust content on gender and cultural perspectives about the military and security (Brown 2018).

\section{Masculinist Culture and the Warrior Archetype}

Participants observed a masculinist culture that privileges whiteness, the English language, heterosexuality, and combat warrior identities at CFC. CFC culture was determined to constitute a significant social barrier to the equal and equitable treatment of female, racialized, linguistic, and sexual and gender minorities in the learning environment. This dominant intersectional identity is described in the responses below from two female students. The first notes that there is an institutional bias towards a masculine warrior archetype, where the combat identity is privileged over others. The second points to a cultural preference for institutionally masculinized "operator" roles that are boots-onthe-ground and door-kicking rather than more feminized "support" roles.

$\mathrm{Oh}$ no, it is not equal. But the rivalries inside the military are very prevalent at JCSP. There is definitely a bias towards the combat arms, but that is the reality. It is not just a JCSP thing.... I think there is an order in the military, and I think it is reproduced in JCSP.

Operators are the most important and they are always right.... I have even heard people say, "I don't care, you are just going to support wherever we decide to go.”... It is viewed as a competition.

These inequalities of power and status were also observed along other intersectional lines such as language, racialization, and gender, or through idealizations of "alpha" warrior masculinities, ethnocentric views, and in some cases, misogynist thinking. Student participants perceived that these idealizations and norms created a culture antagonistic to women, racialized, and Francophone members; noting in par- 
ticular the feminization, or marginalization of, Francophone culture comparatively to Anglophone culture. The following exchange between male student participants highlights the marginalization of Francophone culture:

The white male who is standing over me ticking me [marking my participation] is the one judging how you think, how you sit, how you talk and how you present yourself. That has tremendous impact on anyone, and when you speak French, and someone right away corrects you for doing that, that affects everyone. That micro aggression: "everyone who is French, or Franco speaking, has to leave and go to another room because we have to sort out the bilingual problems you guys have" well, what does that say?

That was brilliant. That was awesome [sarcasm].

How is that inclusive and how does that help the bilingual problem within the College? It's not everyone who speaks French who has the problem, and they need to leave! Then the micro aggression and things that go on at this school, when you start to pick at it, is huge!

This exchange and the previous quotations combine to show the intersectional and gendered social hierarchies produced in the learning environment. They indicate the narrowly idealized ways in which military identity is understood in relation to maleness, masculinity, whiteness, Anglophone culture, and heterosexuality. Participants across all subgroups overwhelmingly noted the hegemony of the Army, and in particular, Army warrior constructs. Participants routinely spoke to how these constructs were given meaning in and through intersecting idealizations of gender, race, language, and sexuality. The privileging of these intersecting identities was observed to produce clear intersectional social hierarchies in the classroom where the attitudes, worldviews, and behaviours that destabilized dominant gender constructions were heavily policed by some educators and peers but were also actively pursued by others (Brown 2018).
Inadequate Explanations of Gender and Intersectional Inequality

Participants observed that the integration of gender and cultural perspectives was incoherent and sometimes presented in confusing ways. Gender, as a concept, was identified to have often been left unexamined. As one of the female student participants noted:

I think the way that gender is being instructed is not well explained, people still don't understand the difference between masculinity and femininity as traits and what that means from a gender perspective.... People associate gender with men and women.... A lot of people are getting fed up with talking about gender, but I think they just don't understand what it means and that is why we need to talk about it more.

Participants also noted that gender perspectives were often conflated with women. For example, a military faculty member argued that:

We have a tendency in this group to talk about gender equaling women. Alright, but gender equals much more than just women. So, when we did the case study and they wrote on gender in Colombia, that whole paper started to focus on women and women's rights in Colombia. When we talk about gender, we need to broaden our perspectives ourselves as in "this is actually broader than just a women discussion."

Furthermore, participants expressed that applications of GBA+ in curriculum were often related to women's integration and Operation HONOUR (sexual misconduct) exclusively and prevented discussion of gender, power, and inequalities. As one female student observed:

A lot of times when we talked about gender in the military, the discussion about Operation HONOUR always comes back. And Operation HONOUR is not just about women. So, they associate the two together, the same way they associate gender with women. 
These conflations and misunderstandings were linked by participants to feelings of fatigue and apathy about applications of gender perspectives and GBA+.

Limitations in teaching about cultural perspectives were also observed. Faculty members noted that the absence of these perspectives in JCSP curriculum has minimized opportunities for senior military officers to develop critical reflection skills necessary to confront personal and institutional bias. They found that limited content on cultural perspectives may have constrained students' opportunities to learn about the views and experiences of people located at the margins of power in society. Despite these limitations, my research also indicates the positive impact that learning about cultural perspectives has had on senior officers' leadership and work.

\section{Feminist Progress in Military Leaders' Localized Practices of Transformation}

Drawing on follow up interviews with eight programme graduates, my research illuminates how senior officers have applied their learning towards localized practices of transformation aimed at disrupting patriarchal social orders and fostering intersectional equality. Some examples include awareness raising, bias interruption, and facilitating shifts in thinking.

The following experience was recounted by a male graduate:

We needed to do a suicide awareness brief on the wing. The intent was to bring in the families. So, automatically...the idea was for the families, for the spouses, we would do a briefing at night because automatically that's the best option right?... So that's when I stopped like "Ok, let's look at who we have ... what about if the spouses are not working or they are at home during the day? It might be easier for them to come in [the day] because their kids are at school. And what about the ones that have a child at home?"... So, it was kind of questioning the assumption that "the spouses will come at night and that's it."... Outside of that, it's been mostly in terms of discussions with other soldiers ... [on] assumptions about recruitment, the quotas about how many women we need in the CF and things like this. So that's how I kind of include it in my daily work...the few times that it came up, it was obvious that what I've learned was of value.

In addition to awareness raising, some participants also spoke about their work towards broader organizational shifts by advocating for policy change. Some reflected on their role in changing procurement policies to reflect the needs of diverse Canadian military members, while others recalled their influence to shifts in comportment and dress policy to better accommodate diverse bodies and gender identities.

The following reflection from a female graduate shows her experience of mainstreaming gender and cultural perspectives in personnel policy:

I make sure it's included. It would be part of the GBA+ protocol, but nobody was doing it before I got here. I work mostly with the Gender Advisor of the Command.... A good example, men are able to wear a beard now. So, the minute that conversion came out, I contacted the dress company and I asked "Ok so when are we going to do the full gender, like the GBA+ analysis and consider some changes for women?" And as an example, like the way women have to wear their hair. And they go "We're not ready for that." I'm like "I don't care if you are not ready, we as a society are there, so we need to move on with it."

In addition to ensuring that gender and cultural perspectives are included in military policy, some participants also indicated that they used their knowledge to request disaggregated information on sex, gender, and other intersectional identity factors such as ethnicity, age, and ability to inform policy, procurement, and operational planning decisions. These actions and analyses by senior officers set the conditions for meaningful feminist progress within the institution, changes that create a more inclusive and equitable work environment for women, men, and gender diverse individuals. 
Two officers deployed on international missions described using gender and cultural perspectives to tailor their approach and conduct in operations with local communities. Each reflected on power disparities in gender, sex, and age, as well as competing cultural interests in specific regions. Both indicated the value of applying gender and cultural perspectives to their work, but, each also stated that gaps in PME about how to conduct gender and intersectional analyses led them to do more independent learning on the fly during missions such as consulting online courses and reaching out to peers that had formal gender education and training (Brown 2018). These examples of the application of gender and intersectional perspectives indicate deep consideration of institutional, interpersonal, and personal bias. They demonstrate efforts to uncover and address inequalities. They illuminate how gender and cultural learning in PME has contributed to military members' localized efforts towards meaningful social transformation and change.

\section{Conclusion}

The transformational work of these senior officers to influence military policy, raise awareness, and address gender and intersectional inequality breaks with generalized narratives of the self-serving motivations for militaries to employ gender perspectives. The officers' articulation of cases, practices, and examples in which they intentionally used a range of gender expressions and perspectives to promote peace and security and work towards broader visions of intersectional equality demonstrates that the integration of feminist perspectives within PME has transformative potential. The insights of this research contribute to a small but growing literature that views the military as a space within which feminists can work towards meaningful change.

The experiences and observations of this study's participants indicate a process of negotiation and efforts to disrupt inequitable social hierarchies within the military and societies. Work to make "small changes that [may] seem superficial" (Duncanson and Woodward 2016 , 11) illustrates that some military members are drawing on feminist education for the intrinsic goal of achieving gender equality and peace rather than leveraging gender to win wars. Such localized interventions resist determinist thinking "even in an institution where change might appear least likely" (Ibid.).

Taber writes that the military "must fundamentally rethink what it means to be a man, a woman, or someone who does not fit into that binary" (2018, 105). She argues that "masculinization must be challenged as a route to successful military membership just as feminization must be challenged as a way to devalue and objectify people" (Ibid.). My research demonstrates that some senior officers have used this learning to do just that. Their internalization and practice of the few feminist and intersectional theories and frameworks that have been presented to them has enabled their contributions to feminist progress, even within a context resistant to feminist thinking and practice. Their localized interventions have worked to "regender" the military by presenting alternative feminist visions to counter dominant patriarchal and white-privileging constructions.

Yet, more work is required to integrate gender and cultural perspectives "to the degree that [they are] always considered as an essential and integral element of all CAF activities" (Chief of Defence Staff 2016b). Gender and cultural perspectives must be formally built into core elements of training and education. This education must be delivered by military and civilian faculty with demonstrated knowledge and expertise in these areas. Importantly, this education must work to identify and challenge patriarchal power arrangements, masculinist constructions of military identity, and cultural resistance to intersectional equality. It must encourage equity, social justice, and the full and meaningful participation of women, Black, Indigenous, people of colour, and LGBTQ2I people. This education must promote diversity and inclusion. Finally, this education must situate military members within the process of transformative feminist progress, so they can see themselves as important agents of change. 


\section{References}

Allen, Charles. D. 2010. "Redress of Professional Military Education: The Clarion Call." Joint Forces Quarterly 59 (4): 94-100.

Australian Government. 2020. "Gender Advisor Course.” Department of Defence, Australian Defence College. https://www.defence.gov.au/ADC/adftc/ POTC/

Gender_Adviser.asp\#:-:text=The\%20aim\%20of\%20th e\%20GENAD, conduct $\% 20$ of $\% 20$ operations $\% 20$ or $\%$ 20exercises.

British Ministry of Defence. 2020. "Human Security Advisor Course.” Defence Academy of the United Kingdom. https://www.da.mod.uk/course/HSA.

Brown, Katherine and Victoria Syme-Taylor. 2012. "Women Academics and Feminism in Professional Military Education." Equality, Diversity and Inclusion: An International Journal 31 (5/6): 452-66.

Brown, Vanessa. 2018. Report on the Integration of Gender and Cultural Perspectives and an Inclusive Learning Environment in the Joint Command and Staff Programme. Prepared for Canadian Forces College.

Brown, Vanessa, and Alan Okros. 2018. "New Leaders, 'New Wars': A Reflective Approach to Applying Gender and Cultural Perspectives." In From "Knowing" to "Doing": International Perspectives on Leading Effectively, edited by Daniel Watola and Allister MacIntyre: 235-90. Kingston, ON: Canadian Defence Academy Press.

Butler, Judith. 2007. Gender Trouble: Feminism and the Subversion of Identity. Routledge Classics. NY:

Routledge.

Chief of Defence Staff. 2009. Duty with Honour: The Profession of Arms in Canada (2nd ed.). Kingston:

Canadian Forces Leadership Institute.

Chief of Defence Staff. 2015. "CDS Op Order - Op HONOUR.” https://www.canada.ca/en/department- national-defence/services/benefits-military/conflictmisconduct/operation-honour/orders-policiesdirectives/cds-operation-order.html.

Chief of Defence Staff. 2016a. Canadian Armed Forces Diversity Strategy. Ottawa: Directorate of Human Rights and Diversity.

Chief of Defence Staff. 2016b. "CDS Directive for Integrating UNSCR 1325 and Related Resolutions into CAF Planning and Operations." https:// www.canada.ca/en/department-national-defence/ services/operations/military-operations/conduct/cdsdirective-unscr-1325.html.

Cockburn, Cynthia. 2010. "Gender Relations as Causal in Militarization and War.” International Feminist Journal of Politics 12 (2): 139-57.

Cockburn, Cynthia. 2011. "Snagged on the Contradiction: NATO UNSC Resolution 1325, and Feminist Responses.” Unpublished manuscript. http:// www.cynthiacockburn.org/BlogNATO1325.pdf.

Cohn, Carol. 2008. "Mainstreaming Gender in UN Security Policy: A Path to Political Transformation.” In Analysing and Transforming Global Governance: Feminist Perspectives, edited by Shirin M. Rai, and Georgina Waylen. Cambridge: Cambridge University Press.

Cook, Nancy. 2007. Gender Relations in Global Perspective: Essential Readings. Toronto, ON: Canadian Scholars Press Inc.

Davis, Karen, ed. 2007. Women and Leadership in the Canadian Forces: Perspectives and Experience. Kingston, ON: Canadian Defence Academy Press.

De Beauvoir, Simone. 1949. The Second Sex. Translation by Constance Borde and Sheila MalovanyChevallier, NY: Vintage Books.

Deschamps, Marie. 2015. External Review into Sexual Misconduct and Sexual Harassment in the Canadian Armed Forces. National Defence and the Canadian 
Forces. https://www.canada.ca/en/departmentnational-defence/corporate/reports-publications/ sexual-misbehaviour/external-review-2015.html.

Deschaux-Beaume, Delphine. 2012. "Investigating the Military Field: Qualitative Research Strategy and Interviewing in the Defence Networks." Current Sociology 60 (1): 101-17.

Dijk, Teun. 1993. "Principles of Critical Discourse Analysis.” Discourse \& Society 4 (2): 249-83.

Duncanson, Claire. 2015. "Hegemonic Masculinity and the Possibility of Change in Gender Relations." Men and Masculinities 18 (2): 231-48.

Duncanson, Claire, and Rachel Woodward. 2016. "Regendering the Military: Theorizing Women's Military Participation." Security Dialogue 47 (1): 3-21.

Duriesmith, David. 2017. Masculinity and New War: The Gendered Dynamics of Contemporary Armed Conflict. Abingdon, Oxon; New York, NY: Routledge.

Duriesmith, David. 2019. "Engaging or Changing Men? Understandings of Masculinity and Change in the New 'Men, Peace and Security' Agenda." Peacebuilding, 1-14. https://www.tandfonline.com/doi/ full/10.1080/21647259.2019.1687076

Eichler, Maya. 2014. "Militarized Masculinities in International Relations." The Brown Journal of World Affairs 21 (1): 81-93.

Elshtain, Jean Bethke. 1987. Women and War. New York: Basic Books.

Eriksson Baaz, Maria, and Maria Stern. 2009. "Why Do Soldiers Rape? Masculinity, Violence and Sexuality in the Armed Forces in the Congo." International Studies Quarterly 53: 495-518.

Global Affairs Canada. 2018. "GBA+ for DND \& CAF: An Institutional Approach.” Centre for Intercultural Learning: Canadian Foreign Service Institute.
Hacking, Ian. 1999. The Social Construction of What? Cambridge, Mass: Harvard University Press.

Johnstone, Rachael, and Bessma Momani. (n.d.). "GBA+ Policy Brief." Canadian Network for Defence and Security Analysis.

Joost, Mathias. 2015. "Racism and Enlistment: The Second World War Policies of the Royal Canadian Airforce." Canadian Military History 21 (1): 17-34.

Kaldor, Mary. 2012. New and Old Wars: Organized Violence in a Global Era. Cambridge, Mass: Polity Press.

Kirby, Paul, and Laura Shepherd. 2016. "The Futures Past of the Women, Peace and Security Agenda." International Affairs 92 (2): 373-92.

Madsen, Chris. 1999. Another Kind of Justice: Canadian Military Law from Confederation to Somalia. Vancouver: UBC Press.

Masters, Cristina. 2005. "Bodies of Technology: Cyborg Soldiers and Militarized Masculinities." International Feminist Journal of Politics 7 (1): 112-32.

McClintock, Anne. 1995. Imperial Leather: Race, Gender, and Sexuality in the Colonial Contest. London; New York: Routledge.

National Defence. 2017. Strong, Secure, Engaged: Canada's National Defence Policy. National Defence.

Office of the Auditor General. 2009. Spring Report of the Auditor General. https://www.oag-bvg.gc.cal internet/English/ parl_oag_200905_01_e_32514.html.

Office of the High Commissioner Human Rights (OHCHR). "Convention on the Elimination of All Forms of Discrimination against Women New York, 18 December 1979." United Nations. https:// www.ohchr.org/en/professionalinterest/pages/ cedaw.aspx. 
Okros, Alan, and Denise Scott. 2015. "Gender Identity in the Canadian Forces: A Review of Possible Impacts on Operational Effectiveness." Armed Forces and Society 41 (2): 243-56.

Parpart, Jane, and Kevin Partridge. 2015. "Soldiering On: Pushing Militarized Masculinities into New Territory." In The SAGE Handbook of Feminist Theory, edited by Mary Evans, Clare Hemmings, Marsha Henry, Hazel Johnstone, Sumi Madhok, Ania Plomien, and Sadie Wearing, 550-65. London: SAGE Publications Ltd.

Persyn, John, and Cheryl Polson. 2012. "Evolution and Influence of Military Adult Education." New Directions for Adult and Continuing Education 136: 516.

Razack, Sherene. 2004. Dark Threats and White Knights: The Somalia Affair, Peacekeeping, and the New Imperialism. Toronto, ON: University of Toronto Press.

Sasson-Levy, Orna. 2003. "Feminism and Military Gender Practices: Israeli Women Soldiers in 'Masculine’ Roles.' Sociological Inquiry 73: 440-65.

Schippers, Mimi. 2007. "Recovering the Feminine Other: Masculinity, Femininity, and Gender Hegemony." Theoretical Sociology 36: 85-102.

Segal, Mady. 1999. "Gender and the Military.” In Handbook of the Sociology of Gender, edited by Janet S. Chafetz, 563-81. New York: Kluwer Academicl Plenum Publishers.

Segal, Lynne. 2008. "Gender, War and Militarism: Making and Questioning the Links." Feminist Review 88: 21-35.

Shildrick, Margrit. 1997. Leaky Bodies and Boundaries: Feminism, Postmodernism, and (bio)Ethics, London: Routledge.

Sjoberg, Laura. 2011. "Gender, the state, and war redux: Feminist international relations across the 'levels of analysis." International Relations 25 (1): 108-34.

Status of Women Canada. 2018a. "Introduction to GBA+." Government of Canada. https://cfc-swc.gc.ca/ gba-acs/course-cours/eng/modA1/

modA1_01_05.html.

Status of Women Canada. 2018b. "What is GBA+." Government of Canada. https://cfc-swc.gc.ca/gba-acs/ index-en.html.

Swedish Armed Forces. 2020. "NATO Gender Advisor Course.” SWEDINT/NCGM. https:// www.forsvarsmakten.se/en/swedint/nordic-centre-forgender-in-military-operations/courses-at-ncgm-andhow-to-apply2/nordefco-gender-advisor-course/.

Taber, Nancy. 2009. "The Profession of Arms: Ideological Codes and Dominant Narratives of Gender in the Canadian Military." Atlantis: A Women's Studies Journal 34: 27-36.

Taber, Nancy. 2015. "Intersecting Discourses of Gender: Military and Academic Gendered Organizations." International Journal of Lifelong Education 34 (2): 230-46.

Taber, Nancy. 2018. "After Deschamps: Men, Masculinities, and the Canadian Armed Forces." Journal of Military, Veteran and Family Health 4(1): 100-7.

Theweleit, Klaus. 1987. Male Fantasies, Vol. 1. Cambridge: Polity Press.

United Nations. 1995. "Beijing Declaration and Platform for Action.” United Nations Fourth World Conference on Women. www.un.org/womenwatch/ daw/beijing/pdf/BDPfA\%20E.pdf

United Nations Security Council. 2000. Resolution 1325. http://unscr.com/en/resolutions/doc/1325.

Whitworth, Sandra. 2005. "Militarized Masculinities and the Politics of Peacekeeping: The Canadian Case." In Critical Security Studies in World Politics, edited by 
Ken Booth, 89-106. Boulder, CO: Lynne Rienner Publishers.

Woodward, Rachel, and Winter, Trish. 2007. Sexing the Soldier: The Politics of Gender and the Contemporary British Army. London: Routledge. 